\title{
Effect of Reinforcement on Deflection and Cracks in Baked Clay Beams
}

\author{
Nawab Ali Lakho, Muhammad Auchar Zardari* \\ Department of Civil Engineering, Quaid-e-Awam University of Engineering, Science and Technology, Nawabshah, Pakistan \\ Email: *muhammad.auchar@quest.edu.pk
}

How to cite this paper: Lakho, N.A. and Zardari, M.A. (2016) Effect of Reinforcement on Deflection and Cracks in Baked Clay Beams. Engineering, 8, 684-690. http://dx.doi.org/10.4236/eng.2016.810062

Received: September 1, 2016

Accepted: October 7, 2016

Published: October 10, 2016

Copyright $\odot 2016$ by authors and Scientific Research Publishing Inc. This work is licensed under the Creative Commons Attribution International License (CC BY 4.0).

http://creativecommons.org/licenses/by/4.0/ (c) (i) Open Access

\begin{abstract}
For low cost houses in Pakistan, Reinforced Baked Clay (RBC) is considered to be a potential construction material as a substitute of Reinforced Cement Concrete (RCC). Deflection and cracks are important parameters for design of beams in a building. However, for RBC beams it is still unknown that how the deflection and crack width could be controlled by increasing ratio of reinforcement. This study investigates the effect of ratio of reinforcement on deflection and cracking behaviour of baked clay beams. The results show that by increasing area of reinforcement by $50 \%$ in baked clay beams: 1) deflection was decreased to 2.5 times, and 2) crack width was reduced to three times.
\end{abstract}

\section{Keywords}

Baked Clay, Deflection, Crack Width, Reinforcement, Ultimate Load, Low Cost Houses

\section{Introduction}

It is financially difficult for low income people of Pakistan to construct their houses due to high cost of aggregates, cement and steel. Therefore, it is need of time to utilize indigenous and low cost materials of building construction. In an initial attempt, pre-cast panels of Reinforced Baked Clay (RBC) beams were manufactured and tested. Literature survey indicates that it is possible to achieve compressive strength of baked clay as high as normal weight concrete. The previous studies suggest that the pre-cast panels of RBC beams can be used as a substitute of RCC beams in a building [1]-[10].

Cracks in concrete beams occur due to deflection. If the deflection in beams is more than allowable limits specified by codes, it may cause damage to walls, windows, false ceiling etc. [11]. If the cracks are wide, water may enter and cause corrosion of reinforcing bars. Due to corrosion, the strength of a structural member may be gradually decreased. 
Baked clay is a brittle material, and like concrete, it is strong in compression and weak in tension. Therefore, steel reinforcement is provided in tension zone of baked clay beams. The available literature is silent regarding the effect of reinforcement on deflection and crack width of baked clay beams. Hence, structural behaviour of RBC beams reinforced with different ratios of reinforcement needs to be investigated. For this purpose, an experimental study was conducted to investigate the effect of increasing reinforcement on mid span deflection and crack width of singly reinforced baked clay beams.

\section{Materials and Methods}

\subsection{Reinforced Baked Clay Beams}

Clay and pit sand were quarried locally and were mixed in a ratio of 70:30 by weight. Hereafter, this mixture will be referred to as clay. Twenty-two percentage of potable water was mixed with the mixture in order to form a workable paste. Mixing was carried out in a pan mixer for fifteen minutes. Beams of size $150 \mathrm{~mm} \times 300 \mathrm{~mm} \times 1980$ $\mathrm{mm}$ were cast in layers using this moist clay mixture. During casting, the beams were compacted at a pressure of $6 \mathrm{MPa}$ in a Mechanized System [12], as shown in Figure 1. Two steel bars of $25 \mathrm{~mm}$ diameter were placed in tension zone of the beams during casting to create perforations for inserting tensile reinforcement after baking. The clay beams were dried in shade and then fired in a commercial Hoffman kiln at a temperature of $1000^{\circ} \mathrm{C}$. Baked clay beams are shown in Figure 2 .

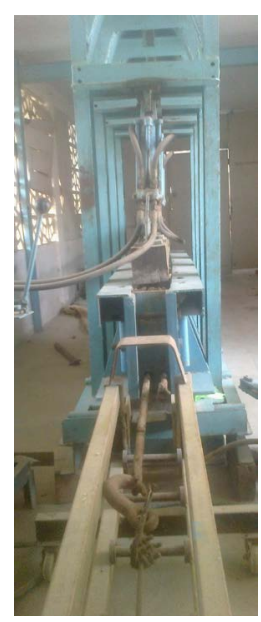

Figure 1. Mechanized system for casting and pressing of clay beams [12].

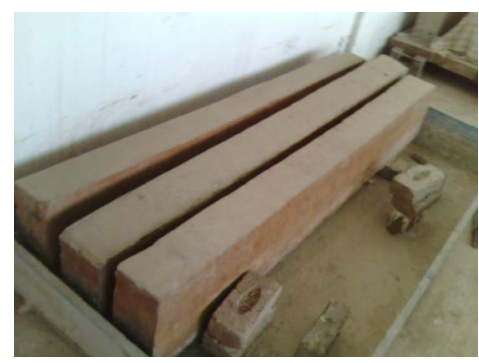

Figure 2. A view of baked clay beams. 
Five baked clay beams were singly reinforced using two $12.7 \mathrm{~mm}$ diameter steel bars (group A). Another three baked clay beams were reinforced using two $16 \mathrm{~mm}$ diameter steel bars (group B). The area of reinforcement used in group B beams is about $50 \%$ more than that of group A beams. In order to reduce possibility of bond-slip, the reinforcing bars were welded to steel anchor plates at both ends of beams. The anchor plates were $150 \mathrm{~mm}$ square with thickness of $12.7 \mathrm{~mm}$. No shear and compressive reinforcement was provided in these RBC beams.

In order to determine the ultimate load carrying capacity, two RBC beams of group A were tested by applying a point load at mid span. In order to examine the effect of ratio of reinforcement on deflection and crack opening displacement, the beams of group $\mathrm{A}$ and $\mathrm{B}$ were subjected to midpoint loading equal to $66 \%$ of the ultimate load at failure. It is to be noted that $66 \%$ of load at failure is considered as total service load [13].

\subsection{Testing Programme}

Cubes of size of $150 \mathrm{~mm}$ [14] were sawed from these baked clay beams. Compressive strength of the baked clay cubes was determined by Universal Testing Machine (Figure 3). Reinforced Baked Clay Beams were tested for deflection and crack width in Universal Beam Testing Machine (Figure 4). The effective length of the RBC beams was 1780 $\mathrm{mm}$. The beams were placed on roller supports during test.

\section{Results and Discussions}

\subsection{Cube Crushing Strength of Baked Clay}

The structural behaviour of singly Reinforced Baked Clay (RBC) beams was studied in terms of 1) cube crushing strength, 2) ultimate load carrying capacity, 3) load versus deflection and 4) load versus crack width. Three of these RBC beams were reinforced with two $12.7 \mathrm{~mm}$ diameter bars (group A) and other three RBC beams were reinforced

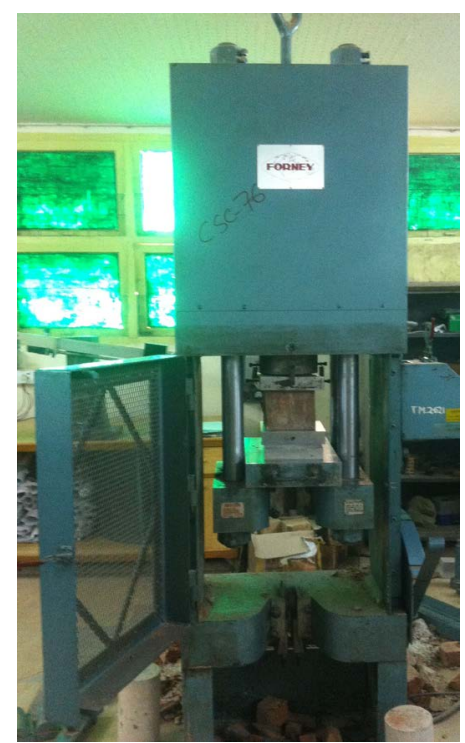

Figure 3. Baked clay cubes are being tested in universal testing machine. 


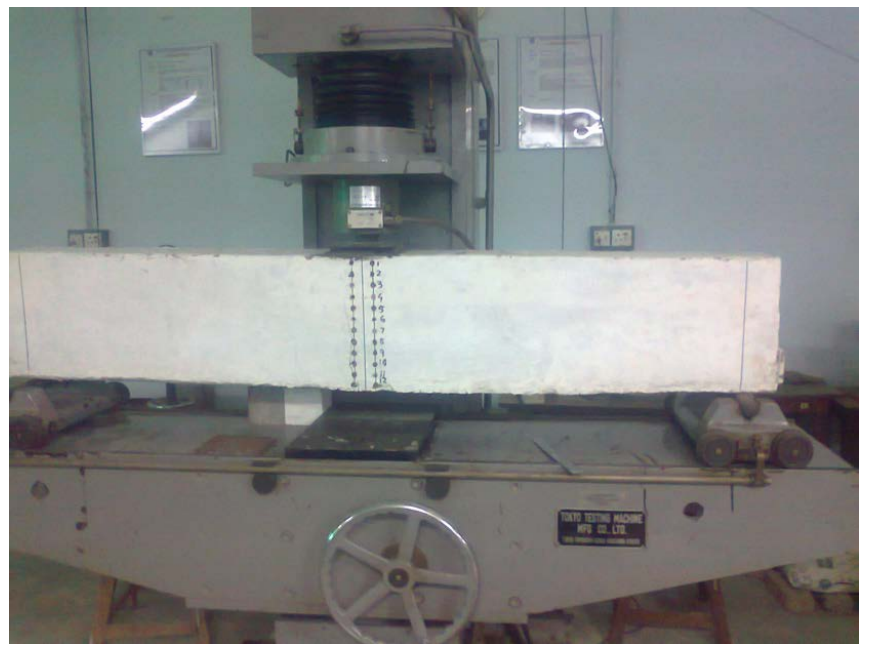

Figure 4. A reinforced baked clay beam is being tested in universal beam testing machine.

with $16 \mathrm{~mm}$ diameter bars (group B). These RBC beams were tested in flexure. The load on the beams was applied up to two-third (i.e.66\%) of the load at failure.

\subsection{Ultimate Load Carrying Capacity of Reinforced Baked Clay Beams}

Two RBC beams of group A (singly reinforced with two $12.7 \mathrm{~mm}$ diameter steel bars) were loaded at mid span up to ultimate failure. The average ultimate load carrying capacity of the RBC beams of group A was found to be $80 \mathrm{kN}$. At the time of failure, flexural cracks occurred in tension zone but no shear cracks were observed in the beams. It is to be noted that at the time of failure, no spalling of baked clay occurred at the bottom or sides of the beam. The failure of beams commenced by opening of a single crack at mid span in tension zone. On further loading, this crack widened and propagated upwards to the top of the beam. On further loading, the steel bars failed by necking at an average load of $80 \mathrm{kN}$. The results suggest that baked clay beams compacted at 6 $\mathrm{MPa}$ and fired at $1000^{\circ} \mathrm{C}$, do not need shear reinforcement. This implies that saving in terms of cost of reinforcement can be achieved.

\subsection{Deflection and Cracking Behaviour of Reinforced Baked Clay Beams}

Figure 5 shows the load deflection curves of RBC beams belonging to groups A and B. As expected, the beams with more ratio of reinforcement (group B) showed less deflection as compared to that of the beams reinforced with lesser ratio of reinforcement (group A). The results show that mid span deflection of RBC beams was reduced to 2.5 times by increasing $50 \%$ area of steel.

Figure 6 shows the cracking behaviour of the RBC beams reinforced with different ratio of reinforcement. The crack width in $\mathrm{RBC}$ beams reinforced with lesser ratio of reinforcement (group A) was observed to be three times more as compared to those reinforced with more ratio of reinforcement (group B). This is a significant result because three times reduction in crack width of RBC beams was achieved by increasing $50 \%$ area of steel. Since these baked clay beams were comparatively stronger in com- 


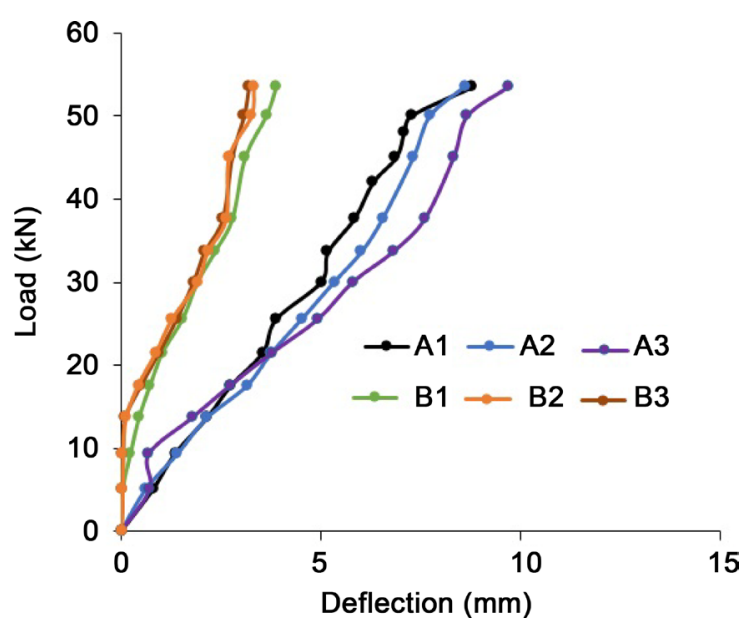

Figure 5. Load versus deflection response of RBC beams of group A (each consisting of two 12.7 $\mathrm{mm}$ diameter steel bars) and group B (each consisting of two $16 \mathrm{~mm}$ diameter steel bars).

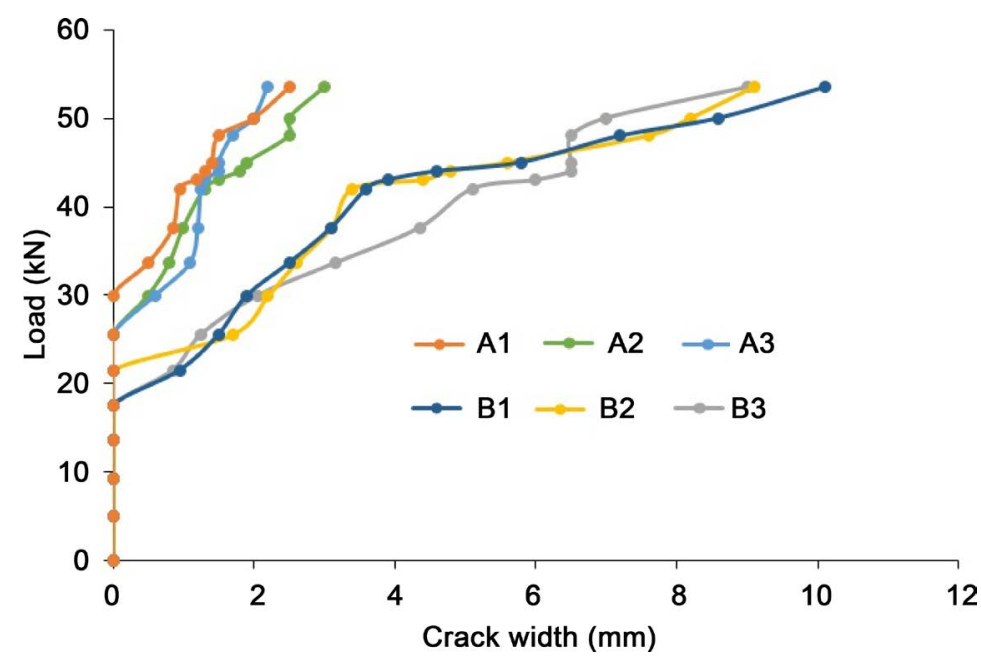

Figure 6. Load versus crack width response of RBC beams of group A (each consisting of two $12.7 \mathrm{~mm}$ diameter steel bars) and group B (each consisting of two $16 \mathrm{~mm}$ diameter steel bars).

pressive strength than normal concrete. The increase in amount of steel resulted in more stiffness of the RBC beams. As a result of this, both the deflection and crack width of RBC beams was decreased.

\section{Conclusions}

In this paper, the effect of ratio of reinforcement on deflection and cracking behaviour of baked clay beams was investigated. Following conclusions can be drawn:

1) Mid-span deflection of RBC beams was reduced to 2.5 times by increasing $50 \%$ area of steel.

2) Crack width in RBC beams was decreased to three times when the area of steel was increased to $50 \%$.

3) Baked clay is considered as homogenous material and its compressive strength used in this study is 1.5 times more that of normal weight concrete. It is suggested that 
the effect of ratio of reinforcement on variation of neutral axis depth should be investigated.

\section{Acknowledgements}

The authors would like to thank Quaid-e-Awam University of Engineering, Science and Technology Nawabshah, for providing access to the Structural Engineering Laboratory to conduct the tests mentioned in this study.

\section{References}

[1] Ansari, A.A., Bhatti, N.K. and Bhutto, A. (2013) Suitability of Pre-Perforated Post-Reinforced Baked Clay Beam Panels for Low Cost Housing. American Journal of Civil Engineering, 1, 6-15. http://dx.doi.org/10.11648/j.ajce.20130101.12

[2] Ansari, A.A. and Lakho, N.A. (2013) Determination of Structural Properties of Baked Clay as Replacement of RCC. International Journal of Emerging Technology and Advanced Engineering, 3, 17-25.

[3] Ansari, A.A. (2008) Experimental Study of the Behaviour of Pre-Perforated Post-Reinforced Baked Clay Panels of Beams. Ph.D. Thesis, Quaid-e-Awam University of Engineering Science and Technology, Nawabshah.

[4] Lakho, N.A. and Zardari, M.A. (2016) Comparison of Compressive and Tensile Strength of Baked Clay with Those of Normal Concrete. Engineering, 8, 301-307. http://dx.doi.org/10.4236/eng.2016.86027

[5] Lakho, N.A. and Zardari, M.A. (2016) Relation between Compressive Strength of Baked Clay Cubes and Cylinders. Engineering, 8, 509-514. http://dx.doi.org/10.4236/eng.2016.88047

[6] Lakho, N.A., Zardari, M.A. and Memon, F.A. (2016) Effect of Intensity of Compaction on Crushing Strength of Indigenous Baked Clay. Journal of Engineering Research, 4, 17-28. http://dx.doi.org/10.7603/s40632-016-0011-5

[7] Lakho, N.A. and Zardari, M.A. (2016) Flexural Behaviour of Reinforced Baked Clay Beams. Engineering, 8, 403-409. http://dx.doi.org/10.4236/eng.2016.87037

[8] Lakho, N.A. and Zardari, M.A. (2016) Experimental Study of Flexural Behaviour of Reinforced Baked Clay Beams under Impact Loading. Engineering, 8, 347-352. http://dx.doi.org/10.4236/eng.2016.86032

[9] Lakho, N.A., Zardari, M.A. and Memon, N.A. (2016) Effect of Firing on Cracking and Warping of Clay Beams. Mehran University Research Journal of Engineering and Technology, 35, 247-252.

[10] Lakho, N.A., Zardari, M.A. and Memon, N.A. (2015) Reduction of Cracking and Shrinkage in Compressed Clay Beams during Drying. Mehran University Research Journal of Engineering and Technology, 35, 395-400.

[11] Gilbert, R.I. (2001) Shrinkage, Cracking and Deflection-The Serviceability of Concrete Structures. Electronic Journal of Structural Engineering, 1, 2-14.

[12] Lakho, N.A, Zardari, M.A., Memon, M. and Saand, A. (2015) Design and Fabrication of Mechanized System for Casting and Compacting Laboratory Size Clay Beams. Scientia Iranica, 22, 2046-2051.

[13] Mirza, S.A., Hyttinen, V. and Hyttinen, E. (1996) Physical Tests and Analyses of Composite 
Steel-Concrete Beam-Columns. Journal of Structural Engineering, 122, 1317-1326.

http://dx.doi.org/10.1061/(ASCE)0733-9445(1996)122:11(1317)

[14] BS EN 12390-3 (2009) Testing Hardened Concrete-Part 3: Compressive Strength of Test Specimens. Management Centre, Brussels.

Submit or recommend next manuscript to SCIRP and we will provide best service for you:

Accepting pre-submission inquiries through Email, Facebook, LinkedIn, Twitter, etc.

A wide selection of journals (inclusive of 9 subjects, more than 200 journals)

Providing 24-hour high-quality service

User-friendly online submission system

Fair and swift peer-review system

Efficient typesetting and proofreading procedure

Display of the result of downloads and visits, as well as the number of cited articles

Maximum dissemination of your research work

Submit your manuscript at: http://papersubmission.scirp.org/

Or contact eng@scirp.org 